\title{
A novel 111/121 diplotype in the Calpain-10 gene is associated with type 2 diabetes
}

Received: 16 January 2006/ Accepted: 30 March 2006/Published online: 24 May 2006

(C) The Japan Society of Human Genetics and Springer-Verlag 2006

\begin{abstract}
Genetic variations in the Calpain-10 gene, CAPN10, have been reported to be associated with the risk of type 2 diabetes mellitus (T2DM) in MexicanAmericans and Northern Europeans whereas these variations are not associated with T2DM in other populations. The aim of this study was to determine whether there is an association between specific CAPN10 diplotype (SNP-43, -19, and -63) and T2DM in the Korean population. Overall, 454 Korean patients with T2DM (male 230, female 224) and 236 non-diabetic controls (male 124, female 112) with no family history of diabetes were enrolled in this study. All the subjects were genotyped according to CAPN10 SNP-43, -19, and -63. The restriction fragment length polymorphism method was used for the three SNPs. There were eight estimated haplotype allelic variations. After adjusting for gender and age, the 111 haplotype was associated with a high risk of T2DM $(P<0.0001)$. The $111 / 121$ diplotype was associated with a high risk of T2DM (odds
\end{abstract}

H.J. Kim and E.S. Kang contributed equally to this work.

E.S. Kang · C.W. Ahn · B.S. Cha · H.C. Lee $(\bowtie)$

Department of Internal Medicine,

Yonsei University College of Medicine,

134 Shinchondong, Sedaemungu, Seoul, Korea

E-mail: endohclee@yumc.yonsei.ac.kr

Tel.: + 82-2-22281943

Fax: + 82-2-3616884

E.S. Kang · C.W. Ahn - B.S. Cha $\cdot$ H.C. Lee

Institute of Endocrine Research,

Yonsei University College of Medicine, Seoul, Korea

E.S. Kang · H.J. Kim - C.W. Ahn · B.S. Cha - H.C. Lee Brain Korea 21 for Medical Science,

Yonsei University College of Medicine, Seoul, Korea

M. Nam

Department of Internal Medicine,

Inha University College of Medicine, Incheon, Korea

C.M. Nam

Department of Preventive Medicine and Public Health, Yonsei University College of Medicine, Seoul, Korea ratio $=2.580,95 \%$ confidence interval $=1.602-4.155$, $P=0.001)$. The high-risk haplotype $(112 / 121)$ in Mexican-Americans was not significant in our study population. In conclusion, we found that a novel 111/121 diplotype in Calpain-10 gene is associated with T2DM in the Korean population.

Keywords Calpain-10 - Polymorphism - Haplotype · Type 2 diabetes $\cdot C A P N 10$

\section{Introduction}

Type 2 diabetes mellitus (T2DM) is a complex metabolic disease in which multiple genetic effects and metabolic and environmental factors contribute to pathogenesis (McCarthy 2004). A genome-wide search for T2DM genes in Mexican-Americans identified a susceptibility locus on chromosome 2q37.3, NIDDM1, for T2DM (Hanis et al. 1996). Horikawa et al. (2000) identified the Calpain-10 Gene [CAPN10 (MIM 605286)] by fine mapping and positional cloning as a putative T2DM susceptibility gene. CAPN10 is comprised of 15 exons spanning $31 \mathrm{~kb}$ of genomic sequence and encodes a 672 amino-acid intracellular protease. The allele combination of CAPN10 (SNP-43,-19, and -63), is reported to be associated with increased risk of T2DM in many populations (Horikawa et al. 2000; Cassell et al. 2002; Elbein et al. 2002; Lynn et al. 2002; Malecki et al. 2002; Iwasaki et al. 2005), although this is somewhat controversial (Tsai et al. 2001; Daimon et al. 2002; Fingerlin et al. 2002; Chen et al. 2005; $\mathrm{Wu}$ et al. 2005). The 112/121 diplotype of $C A P N 10$ is associated with a 3 -fold increase in the risk of contracting T2DM in Mexican-Americans and in Northern European populations (Horikawa et al. 2000). However, the associations between these genetic variants of CAPN10 and diabetes have not been consistently observed in other populations, including Japanese (Evans et al. 2001; Tsai et al. 2001; Rasmussen et al. 2002; Horikawa et al. 2003; del Bosque-Plata et al. 2004). 
Further studies in other racial populations are still needed to confirm the role of $C A P N 10$ polymorphisms in the pathogenesis of T2DM. The aim of this study was to determine whether there is any association between specific $C A P N 10$ polymorphisms and increased T2DM risk in the Korean population.

\section{Materials and methods}

\section{Subjects and study design}

The study population consisted of 454 unrelated subjects with T2DM and 236 non-diabetic controls. The diagnosis of T2DM was made according to the criteria of the WHO (2003). The age at onset of T2DM in the diabetic subjects was $<60$ years. In order to rule out type 1 or maturity-onset diabetes of the young, the following were excluded from this study: subjects diagnosed before they were 25 years old or subjects receiving insulin therapy within 3 years of the onset of diabetes. The non-diabetic control population consisted only of individuals with a normal fasting glucose level $(<100 \mathrm{mg} / \mathrm{dl})$, no family history of diabetes and who were older than 60 years old. Subjects with late onset ( $>60$ years old) T2DM and younger non-diabetic controls $(<60$ years old) were excluded from the examination to increase genetic power. The study was approved by the Institutional Review Board of Inha University Hospital, and written informed consent was obtained from all participants.

\section{Data collection}

The patients' medical and family histories were recorded. Their blood pressure, height, and weight were measured. Blood samples were collected after an overnight fast to determine fasting plasma glucose, HbAlc, total cholesterol, high-density lipoprotein (HDL)-cholesterol, and triglyceride levels. Concentrations of fasting plasma glucose, total cholesterol, and triglyceride levels were determined using an enzymatic colorimetric assay. The HDL-cholesterol concentration was measured using lipoprotein electrophoresis. The low-density lipoprotein (LDL)-cholesterol level was calculated using the Friedewald formula (Friedewald et al. 1972). The HbA1c value was determined using high-performance liquid chromatography (Greencross, Seoul, Korea). The homeostasis model assessment of insulin resistance (HOMA-IR) was calculated by $\{$ ffasting insulin $(\mu \mathrm{U} / \mathrm{ml}) \times$ fasting glucose $(\mathrm{mmol} / \mathrm{l})] / 22.5\}$. The HOMA-beta cell function was calculated by $[20 \times$ fasting insulin $(\mu \mathrm{U} / \mathrm{ml}) /$ fasting glucose (mmol/1)-3.5] (Matthews et al. 1985; Kang et al. 2005a).

\section{Genotyping analysis}

Three polymorphisms in CAPN10 were genotyped for haplotype analyses as described previously (Evans et al. 2001; Horikawa et al. 2003): SNP-43 (g.4852, $\mathrm{G}>\mathrm{A}, \quad \mathrm{rs} 3792267), \quad$ SNP-19 (g.7920 in/del32bp, rs3842570), and UCSNP-63 (g.1637C > T, rs5030952). The alleles were designated as described by Horikawa et al. (2000). A polymerase chain reaction was performed with genomic DNA using a sense primer, 5'-CACGCTT GCTGTGAAGTAATGC- $3^{\prime}$, and an antisense downstream primer, 5'-CTCTGATTCCCATGGTCTGT AG-3 for SNP-43, 5'-GTTTG GTTCTCTTCAGCGTG GAG-3' and 5'-CATGAACCCTGGCAGGGTCTA AG-3' for SNP-19, and 5'-AGCACTCCC AGCTCCT-

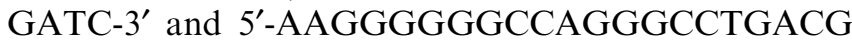
GGGGTGGCG-3" for SNP-63. NsiI (Promega, Madison, WI) and HhaI (Takara Bio, Shiga, Japan) were used to perform restriction fragment length polymorphism analysis.

\section{Statistical analysis}

Genotypic distributions were tested for deviation from the Hardy-Weinberg equilibrium using the chi-square goodness-of-fit test. A comparison of variables between the groups of genotypes was performed using a twotailed Student's $t$-test. Statistical differences in the genotype frequencies between T2DM subjects and the controls were assessed by a chi-square test. In diplotype analysis, odds ratio (OR) and 95\% confidence interval (CI) were calculated by comparing each diplotype with all the other diplotypes as a group. The OR and 95\% CI for the various genotypes were calculated using Fisher's exact test. Statistical analysis of triglyceride, HDL-cholesterol, and LDL-cholesterol levels was performed using log-transformed values because the distribution was not normal. Pairwise linkage disequilibrium (LD) between three Calpain-10 loci was assessed using SAS Genetics (version 9.1, SAS Institute, Cary, NC) statistical package. Haplotype frequencies created by these three SNPs were inferred by a maximum likelihood method using the Haplotyper program (http:// www.people.fas.harvard.edu/ junliu/Haplo/) (Niu et al. 2002; Kang et al. b). Haplotype distributions were analyzed by a likelihood-ratio test. Statistical power was computed using a power calculator program (http:// calculators.stat.ucla.edu/powercalc/). $P$ values $<0.05$ were considered significant.

\section{Results}

A total of 454 unrelated subjects with T2DM and 236 non-diabetic controls were genotyped. There were no gender differences between the two groups. HbAlc, fasting plasma insulin, HOMA-IR, and HOMA-beta cell values in the diabetic patients were $8.4 \pm 3.3 \%$, $83.23 \pm 95.43 \mathrm{pmol} / \mathrm{l}, 4.2 \pm 5.4$, and $62.7 \pm 79.9$, respectively. The body mass index (BMI) and blood pressure were higher in the diabetes patients than that in the nondiabetic controls (Table 1). The diabetes group showed 
Table 1 Clinical characteristics of the study population. $B M I$ Body mass index, $S B P$ systolic blood pressure, $D B P$ diastolic blood pressure, FPG fasting plasma glucose, $L D L$ lowdensity lipoprotein, $H D L$ highdensity lipoprotein

$P$ value by Student's unpaired $t$-test

${ }^{a} P$ value by chi-square test

${ }^{\mathrm{b}} P$ values calculated from $\log$ transformed data

\begin{tabular}{lllr}
\hline & Diabetic & Control & $P$ \\
\hline Number of subjects $(\mathrm{M} / \mathrm{F})$ & $454(230 / 224)$ & $236(124 / 112)$ & $0.689^{\mathrm{a}}$ \\
Age (years) & $53.3 \pm 11.0$ & $62.6 \pm 5.1$ & $<0.001$ \\
BMI $\left(\mathrm{kg} / \mathrm{m}^{2}\right)$ & $24.4 \pm 3.5$ & $23.8 \pm 2.7$ & $<0.01$ \\
SBP $(\mathrm{mmHg})$ & $134.3 \pm 19.1$ & $129.7 \pm 16.4$ & $<0.001$ \\
DBP (mmHg) & $82.4 \pm 10.5$ & $79.6 \pm 9.1$ & $<0.001$ \\
FPG (mmol/l) & $8.3 \pm 2.5$ & $5.1 \pm 0.5$ & $<0.001$ \\
Total cholesterol (mmol/l) & $5.15 \pm 1.03$ & $5.08 \pm 0.85$ & 0.392 \\
Triglyceride (mmol/l) & $2.52 \pm 1.39$ & $1.87 \pm 1.06$ & $<0.001^{\mathrm{b}}$ \\
LDL-cholesterol (mmol/l) & $3.16 \pm 0.94$ & $3.09 \pm 0.82$ & $0.338^{\mathrm{b}}$ \\
HDL-cholesterol (mmol/l) & $1.17 \pm 0.35$ & $1.35 \pm 0.32$ & $<0.001^{\mathrm{b}}$ \\
\hline
\end{tabular}

higher serum triglyceride levels and lower HDL-cholesterol levels than the control group. There was no significant difference in the frequency of SNP-43, -19, and 63 between the diabetic patients and the non-diabetic controls, which is in agreement with previous studies (Table 2) (Horikawa et al. 2000; Daimon et al. 2002). The distribution of each allele did not significantly deviate from Hardy-Weinberg equilibrium (Table 2). The Haplotyper program (Stephens et al. 2001) estimated the haplotype allelic distributions and identified eight alleles (Table 3). Haplotype frequencies were $47.7 \%$ for $121,19.2 \%$ for $112,14.7 \%$ for $111,9.5 \%$ for 122 , and $6.7 \%$ for 221 . The most common haplotype in this study was 121, which is in agreement with other previous studies (Horikawa et al. 2000; Cassell et al. 2002; Fingerlin et al. 2002; Malecki et al. 2002; Wu et al. 2005). Calculations of the LD showed a weak positive LD between these SNPs (Table 4). LD among the three markers $\left(D^{\prime}\right)$ ranged from 0.2383 to 0.5464 (average pairwise $D^{\prime}$ of 0.4423$)$. Likelihood-ratio test revealed that 111 haplotype showed a high risk of T2DM $(P<0.0001$; Table 3$)$. The 121/121 diplotype was associated with significantly decreased risk of T2DM $(\mathrm{OR}=0.660,95 \%$ CI $=0.460-0.948, P=0.029$, power $=63.5 \%$; Table 5). The subjects with $111 / 121$ diplotype showed a high risk of T2DM (OR $=2.580$, $95 \%$ CI $=1.602-4.155, P<0.001$, power $=78.7 \%$;

Table 2 Allele and genotype frequencies of the CAPN10 SNPs. Data are represented as mean $\pm \mathrm{SD}$. Alleles were designated as described by Horikawa et al. (2000): SNP-43 allele $1=\mathrm{G}$, allele $2=\mathrm{A} ; \mathrm{SNP}-19$ allele $1=2 \mathrm{R}$ (two repeats of 32-bp sequences),
Table 5). The 112/121 diplotype, which is reported to be associated with T2DM in Mexican-American and Northern European population (Horikawa et al. 2000; Cox et al. 2004), was not significant in this study.

\section{Discussion}

We previously reported that $111 / 121$ diplotype is associated with metabolic syndrome in patients with T2DM (Kang et al. 2006). In this study we investigated whether the $111 / 121$ diplotype is associated with diabetes or not. Our results show that a novel 111/121 diplotype, defined by the three polymorphic alleles designated SNP-43, -19, and -63 of $C A P N 10$, is associated with increased risk of T2DM in the Korean population. This study also suggests that subjects homozygous for the 121 haplotype have a reduced risk of T2DM. Although Horikawa et al. demonstrated that the $112 / 121$ diplotype confers the highest risk of diabetes in Mexican-Americans $(\mathrm{OR}=2.8)$ (Horikawa et al. 2000; Cox et al. 2004), we found no significant association between the 112/121 diplotype and increased susceptibility to T2DM (OR $=0.693, P=0.077)$. Wu et al. (2005) reported that $112 / 221$ was associated with a reduced risk of T2DM in a Chinese population $(\mathrm{OR}=0.39)$. We did not find a reduced frequency of this diplotype $112 / 221$ in the

allele $2=3 \mathrm{R}$ (three repeats of 32-bp sequences); SNP-63 allele $1=\mathrm{C}$, allele $2=\mathrm{T}$. Haplotypes 211, 212, and 222 were not observed. $P$ value assessed by Hardy-Weinberg equilibrium chisquare test

\begin{tabular}{|c|c|c|c|c|c|c|}
\hline Allele & \multicolumn{2}{|c|}{ Number $(\%)$} & Genotype & \multicolumn{2}{|c|}{ Number $(\%)$} & $P$ \\
\hline $\mathrm{G}$ & $829(91.3)$ & $430(91.1)$ & $\mathrm{G} / \mathrm{G}$ & $388(85.5)$ & $198(83.9)$ & \\
\hline A & $79(8.7)$ & $42(8.9)$ & $\begin{array}{l}\mathrm{G} / \mathrm{A} \\
\mathrm{A} / \mathrm{A}\end{array}$ & $\begin{array}{l}53(11.7) \\
13(2.8)\end{array}$ & $\begin{array}{c}34(14.4) \\
4(1.7)\end{array}$ & \\
\hline \multicolumn{3}{|l|}{ SNP-19 } & & & & \multirow[t]{2}{*}{0.153} \\
\hline $3 \mathrm{R}$ & & & $3 R / 3 R$ & $173(38.1)$ & $107(45.3)$ & \\
\hline SNP-63 & & & & & & \multirow[t]{4}{*}{0.326} \\
\hline C & $647(71.3)$ & $316(66.9)$ & $\mathrm{C} / \mathrm{C}$ & $253(55.7)$ & $120(50.8)$ & \\
\hline \multirow[t]{2}{*}{$\mathrm{T}$} & $261(28.7)$ & $156(33.1)$ & $\mathrm{C} / \mathrm{T}$ & $141(31.1)$ & $76(32.2)$ & \\
\hline & & & $\mathrm{T} / \mathrm{T}$ & $60(13.2)$ & $40(17.0)$ & \\
\hline
\end{tabular}


Table 3 Frequencies of haplotype and the risk of T2DM. The odds ratio and $95 \%$ confidence interval of each haplotype are relative to the other haplotypes as a group. Haplotypes with very rare frequencies $(<5 \%)$ are not shown

\begin{tabular}{llllr}
\hline Haplotype & Diabetic & Control & Total & \multicolumn{1}{l}{$P$} \\
\hline 111 & 0.1765 & 0.0900 & 0.1472 & $<0.0001$ \\
112 & 0.1820 & 0.2133 & 0.1923 & 0.1641 \\
121 & 0.4603 & 0.5104 & 0.4774 & 0.0769 \\
122 & 0.0942 & 0.0972 & 0.0954 & 0.8537 \\
221 & 0.0700 & 0.0624 & 0.0667 & 0.6044 \\
Log-likelihood & $-1,066$ & -542 & $-1,619$ & \\
Degree of freedom & 7 & 7 & 7 & \\
$P$ value & & & 0.004 & \\
\hline
\end{tabular}

Table 4 Linkage disequilibrium (LD) between CAPN10 polymorphisms in the Korean populations

\begin{tabular}{lll}
\hline & $r^{2}$ & $D^{\prime}$ \\
\hline SNP-43-SNP-19 & 0.0135 & 0.5464 \\
SNP-43-SNP-63 & 0.0027 & 0.2383 \\
SNP-19-SNP-63 & 0.2938 & 0.5421 \\
\hline
\end{tabular}

T2DM group compared to the control group $(\mathrm{OR}=$ $0.518, P=0.072)$. The 121 haplotype was reportedly associated with increased risk in European populations (Malecki et al. 2002; Orho-Melander et al. 2002) while being associated with a reduced risk in Japanese (Iwasaki et al. 2005). There was no significant association between diabetic risk and the 121 haplotype in this study; conversely, the 111 haplotype was shown to be associated with an increased risk of T2DM in this study $(P<0.0042)$. Our study also showed that the common 121/121 diplotype appeared to be associated with protection from T2DM in our population $(\mathrm{OR}=0.660$, $95 \%$ CI $=0.460-0.948, P<0.001)$. We examined the association between the CAPN10 SNP-44 genotype and

Table 5 Frequency of diplotype of $C A P N 10$ and the risk of T2DM. The odds ratio (OR) and $95 \%$ confidence interval (CI) of each diplotype are relative to the other diplotype as a group. $P$ values are calculated by Fisher's exact test

\begin{tabular}{lccll}
\hline Diplotype & \multicolumn{2}{l}{ Number $(\%)$} & OR $(95 \%$ CI $)$ & $P$ \\
\cline { 2 - 3 } & Diabetic & Control & & \\
\hline $111 / 111$ & $9(2)$ & $3(1)$ & $1.541(0.413-5.750)$ & 0.759 \\
$111 / 112$ & $14(3)$ & $4(2)$ & $1.811(0.589-5.566)$ & 0.449 \\
$111 / 121$ & $104(23)$ & $24(10)$ & $2.580(1.602-4.155)$ & 0.001 \\
$111 / 221$ & $11(2)$ & $3(1)$ & $1.892(0.523-6.853)$ & 0.404 \\
$112 / 112$ & $26(6)$ & $11(5)$ & $1.218(0.591-2.513)$ & 0.721 \\
$112 / 121$ & $76(17)$ & $52(22)$ & $0.693(0.467-1.030)$ & 0.077 \\
$112 / 122$ & $22(5)$ & $18(8)$ & $0.604(0.317-1.151)$ & 0.124 \\
$112 / 221$ & $13(3)$ & $7(3)$ & $0.946(0.372-2.404)$ & 1.000 \\
$121 / 121$ & $98(22)$ & $68(29)$ & $0.660(0.460-0.948)$ & 0.024 \\
$121 / 122$ & $30(7)$ & $11(5)$ & $1.419(0.698-2.888)$ & 0.396 \\
$121 / 221$ & $19(4)$ & $18(8)$ & $0.518(0.266-1.008)$ & 0.072 \\
$122 / 122$ & $7(2)$ & $5(2)$ & $0.710(0.223-2.261)$ & 0.550 \\
$122 / 221$ & $8(2)$ & $1(0)$ & $4.137(0.514-33.285)$ & 0.285 \\
$221 / 221$ & $10(2)$ & $2(1)$ & $2.059(0.434-9.779)$ & 0.355 \\
& & & &
\end{tabular}

diabetes in a subset of our study population ( 96 diabetes and 96 controls). We found no significant association between $C A P N 10$ SNP-44 and diabetes $(P=0.0 .817)$.

Calpain is a member of a family of calcium-activated intracellular proteases. The CAPN10 gene is located on chromosome $2 \mathrm{q} 37$, encodes at least eight alternative splicing variants, and contains 15 exons spanning $31 \mathrm{~kb}$. Calpain-10 is expressed in many tissues such as the heart, pancreas, brain, liver, skeletal muscle, and kidney (Horikawa et al. 2000), and is essential for multiple cellular functions. The exact molecular mechanisms of how some polymorphisms in the CAPN10 increase susceptibility to T2DM are unclear. However, the polymorphisms of this gene most likely influence glucose uptake in skeletal muscle and adipocytes (Paul et al. 2003; Ridderstrale et al. 2005; Turner et al. 2005) as well as glucose-induced insulin secretion in pancreatic $\beta$ cells (Sreenan et al. 2001; Paul et al. 2003; Zhou et al. 2003; Ridderstrale et al. 2005; Turner et al. 2005).

Most of the haplotype frequencies in our study are similar to those reported by Horikawa et al. (2003) except for the frequency of the significant haplotype 111 (diabetes $16.48 \%$ vs $12 \%$; control $7.95 \%$ vs $9 \%$ ). It is possible that the younger age and increased obesity in our population $(53.3 \pm 11.0$ years old vs $62.0 \pm 11.0$ years old; BMI, $24.4 \pm 3.5 \mathrm{~kg} / \mathrm{m}^{2}$ vs $23.9 \pm 3.3 \mathrm{~kg} / \mathrm{m}^{2}$ ) might have contributed to this discrepancy. Additionally, late onset ( $>60$ years) diabetic subjects were excluded from our study, and our study included a larger number of diabetic subjects (454 vs 177) than the study of Horikawa et al. (2003). The susceptibility locus of the Mexican-Americans, NIDDM1, may also contribute to the development of T2DM in other populations, but each study localized susceptibility to different regions of the genome, which suggests that different combinations of the susceptibility gene contribute to the development of T2DM in each population.

In conclusion, we found that the novel 111/121 diplotype in the Calpain-10 gene is associated with an increased risk of T2DM and that the 121/121 diplotype was associated with a significantly decreased risk of $\mathrm{T} 2 \mathrm{DM}$ in the Korean population.

Acknowledgments This study was supported by the Brain Korea 21 Project for Medical Science, Yonsei University and faculty research grant of Yonsei University College of Medicine for 2005 (6-20050102).

\section{References}

Bosque-Plata L del, Aguilar-Salinas CA, Tusie-Luna MT, Ramirez-Jimenez S, Rodriguez-Torres M, Auron-Gomez M, Ramirez E, Velasco-Perez ML, Ramirez-Silva A, Gomez-Perez F, Hanis CL, Tsuchiya T, Yoshiuchi I, Cox NJ, Bell GI (2004) Association of the calpain-10 gene with type 2 diabetes mellitus in a Mexican population. Mol Genet Metab 81:122-126

Cassell PG, Jackson AE, North BV, Evans JC, SyndercombeCourt D, Phillips C, Ramachandran A, Snehalatha C, Gelding SV, Vijayaravaghan S, Curtis D, Hitman GA (2002) Haplotype 
combinations of calpain 10 gene polymorphisms associate with increased risk of impaired glucose tolerance and type 2 diabetes in South Indians. Diabetes 51:1622-1628

Chen Y, Kittles R, Zhou J, Chen G, Adeyemo A, Panguluri RK, Chen W, Amoah A, Opoku V, Acheampong J, AgyenimBoateng K, Eghan BA Jr, Nyantaki A, Oli J, Okafor G, Ofoegbu E, Osotimehin B, Abbiyesuku F, Johnson T, Fasanmade O, Rufus T, Furbert-Harris P, Daniel HI, Berg KA, Collins FS, Dunston GM, Rotimi CN (2005) Calpain-10 gene polymorphisms and type 2 diabetes in West Africans: the Africa America Diabetes Mellitus (AADM) Study. Ann Epidemiol 15:153-159

Cox NJ, Hayes MG, Roe CA, Tsuchiya T, Bell GI (2004) Linkage of calpain 10 to type 2 diabetes: the biological rationale. Diabetes 53 [Suppl]:S19-S25

Daimon M, Oizumi T, Saitoh T, Kameda W, Yamaguchi H, Ohnuma H, Igarashi M, Manaka H, Kato T (2002) Calpain 10 gene polymorphisms are related, not to type 2 diabetes, but to increased serum cholesterol in Japanese. Diabetes Res Clin Pract 56:147-152

Elbein SC, Chu W, Ren Q, Hemphill C, Schay J, Cox NJ, Hanis CL, Hasstedt SJ (2002) Role of calpain-10 gene variants in familial type 2 diabetes in Caucasians. J Clin Endocrinol Metab 87:650-654

Evans JC, Frayling TM, Cassell PG, Saker PJ, Hitman GA, Walker M, Levy JC, O'Rahilly S, Rao PV, Bennett AJ, Jones EC, Menzel S, Prestwich P, Simecek N, Wishart M, Dhillon R, Fletcher C, Millward A, Demaine A, Wilkin T, Horikawa Y, Cox NJ, Bell GI, Ellard S, McCarthy MI, Hattersley AT (2001) Studies of association between the gene for calpain-10 and type 2 diabetes mellitus in the United Kingdom. Am J Hum Genet 69:544-552

Fingerlin TE, Erdos MR, Watanabe RM, Wiles KR, Stringham HM, Mohlke KL, Silander K, Valle TT, Buchanan TA, Tuomilehto J, Bergman RN, Boehnke M, Collins FS (2002) Variation in three single nucleotide polymorphisms in the calpain-10 gene not associated with type 2 diabetes in a large Finnish cohort. Diabetes 51:1644-1648

Friedewald WT, Levy RI, Fredrickson DS (1972) Estimation of the concentration of low-density lipoprotein cholesterol in plasma, without use of the preparative ultracentrifuge. Clin Chem 18:499-502

Hanis CL, Boerwinkle E, Chakraborty R, Ellsworth DL, Concannon P, Stirling B, Morrison VA, Wapelhorst B, Spielman RS, Gogolin-Ewens KJ, Shepard JM, Williams SR, Risch N, Hinds D, Iwasaki N, Ogata M, Omori Y, Petzold C, Rietzch H, Schroder HE, Schulze J, Cox NJ, Menzel S, Boriraj VV, Chen X, Lim LR, Lindner T, Mereu LE, Wang YQ, Xiang K, Yamagata K, Yang Y, Bell GI (1996) A genome-wide search for human non-insulin-dependent (type 2) diabetes genes reveals a major susceptibility locus on chromosome 2. Nat Genet 13:161166

Horikawa Y, Oda N, Cox NJ, Li X, Orho-Melander M, Hara M, Hinokio Y, Lindner TH, Mashima H, Schwarz PE, del Bosque-Plata L, Horikawa Y, Oda Y, Yoshiuchi I, Colilla S, Polonsky KS, Wei S, Concannon P, Iwasaki N, Schulze J, Baier LJ, Bogardus C, Groop L, Boerwinkle E, Hanis CL, Bell GI (2000) Genetic variation in the gene encoding calpain10 is associated with type 2 diabetes mellitus. Nat Genet 26:163-175

Horikawa Y, Oda N, Yu L, Imamura S, Fujiwara K, Makino M, Seino Y, Itoh M, Takeda J (2003) Genetic variations in calpain-10 gene are not a major factor in the occurrence of type 2 diabetes in Japanese. J Clin Endocrinol Metab 88:244247

Iwasaki N, Horikawa Y, Tsuchiya T, Kitamura Y, Nakamura T, Tanizawa Y, Oka Y, Hara K, Kadowaki T, Awata T, Honda M, Yamashita K, Oda N, Yu L, Yamada N, Ogata M, Kamatani N, Iwamoto Y, Del Bosque-Plata L, Hayes MG, Cox NJ, Bell GI (2005) Genetic variants in the calpain-10 gene and the development of type 2 diabetes in the Japanese population. J Hum Genet 50:92-98
Kang ES, Yun YS, Park SW, Kim HJ, Ahn CW, Song YD, Cha BS, Lim SK, Kim KR, Lee HC (2005a) Limitation of the validity of the homeostasis model assessment as an index of insulin resistance in Korea. Metabolism 54:206-211

Kang ES, Park SY, Kim HJ, Ahn CW, Nam M, Cha BS, Lim SK, Kim KR, Lee HC (2005b) The influence of adiponectin gene polymorphism on the rosiglitazone response in patients with type 2 diabetes. Diabetes Care 28:1139-1144

Kang ES, Nam M, Kim HJ, Kim HJ, Myoung SM, Rhee Y, Ahn CW, Cha BS, Lee HC (2006) Haplotype combination of calpain-10 Gene polymorphism is associated with metabolic syndrome in type 2 diabetes. Diabetes Res Clin Pract (in press)

Lynn S, Evans JC, White C, Frayling TM, Hattersley AT, Turnbull DM, Horikawa Y, Cox NJ, Bell GI, Walker M (2002) Variation in the calpain-10 gene affects blood glucose levels in the British population. Diabetes 51:247-250

Malecki MT, Moczulski DK, Klupa T, Wanic K, Cyganek K, Frey J, Sieradzki J (2002) Homozygous combination of calpain 10 gene haplotypes is associated with type 2 diabetes mellitus in a Polish population. Eur J Endocrinol 146:695-699

Matthews DR, Hosker JP, Rudenski AS, Naylor BA, Treacher DF, Turner RC (1985) Homeostasis model assessment: insulin resistance and beta-cell function from fasting plasma glucose and insulin concentrations in man. Diabetologia 28:412-419

McCarthy MI (2004) Progress in defining the molecular basis of type 2 diabetes mellitus through susceptibility-gene identification. Hum Mol Genet 13S:R33-R41

Niu T, Qin ZS, Xu X, Liu JS (2002) Bayesian haplotype inference for multiple linked single-nucleotide polymorphisms. Am J Hum Genet 70:157-169

Orho-Melander M, Klannemark M, Svensson MK, Ridderstrale M, Lindgren CM, Groop L (2002) Variants in the calpain-10 gene predispose to insulin resistance and elevated free fatty acid levels. Diabetes 51:2658-2664

Paul DS, Harmon AW, Winston CP, Patel YM (2003) Calpain facilitates GLUT4 vesicle translocation during insulin-stimulated glucose uptake in adipocytes. Biochem J 376:625-632

Rasmussen SK, Urhammer SA, Berglund L, Jensen JN, Hansen L, Echwald SM, Borch-Johnsen K, Horikawa Y, Mashima H, Lithell H, Cox NJ, Hansen T, Bell GI, Pedersen O (2002) Variants within the calpain-10 gene on chromosome 2q37 $(N I D D M 1)$ and relationships to type 2 diabetes, insulin resistance, and impaired acute insulin secretion among Scandinavian Caucasians. Diabetes 51:3561-3567

Ridderstrale M, Parikh H, Groop L (2005) Calpain 10 and type 2 diabetes: are we getting closer to an explanation? Curr Opin Clin Nutr Metab Care 8:361-366

Sreenan SK, Zhou YP, Otani K, Hansen PA, Currie KP, Pan CY, Lee JP, Ostrega DM, Pugh W, Horikawa Y, Cox NJ, Hanis CL, Burant CF, Fox AP, Bell GI, Polonsky KS (2001) Calpains play a role in insulin secretion and action. Diabetes 50:2013-2020

Stephens M, Smith NJ, Donnelly P (2001) A new statistical method for haplotype reconstruction from population data. Am J Hum Genet 68:978-989

Tsai HJ, Sun G, Weeks DE, Kaushal R, Wolujewicz M, McGarvey ST, Tufa J, Viali S, Deka R (2001) Type 2 diabetes and three calpain-10 gene polymorphisms in Samoans: no evidence of association. Am J Hum Genet 69:1236-1244

Turner MD, Cassell PG, Hitman GA (2005) Calpain-10: from genome search to function. Diabetes Metab Res Rev 21:505-514

WHO (2003) Report of the expert committee on the diagnosis and classification of diabetes mellitus. Diabetes Care 26(S1):S5-S20

Wu B, Takahashi J, Fu M, Cheng H, Matsumura S, Taniguchi H (2005) Variants of calpain-10 gene and its association with type 2 diabetes mellitus in a Chinese population. Diabetes Res Clin Pract 68:155-161

Zhou YP, Sreenan S, Pan CY, Currie KP, Bindokas VP, Horikawa Y, Lee JP, Ostrega D, Ahmed N, Baldwin AC, Cox NJ, Fox AP, Miller RJ, Bell GI, Polonsky KS (2003) A 48-h exposure of pancreatic islets to calpain inhibitors impairs mitochondrial fuel metabolism and the exocytosis of insulin. Metabolism 52:528 534 